\title{
INDIRECT SPEECH ACTS IN TOBA DREAM MOVIE
}

\author{
Taufan Fadilah \\ Meisuri \\ Isli Iriani Indiah Pane \\ Universitas Negeri Medan
}

\begin{abstract}
This study focused on indirect speech act used by the main characters in Toba Dream movie. The objectives of the study were to: (1) find out the types of indirect speech acts used in Toba Dream movie, and (2) describe how types of indirect speech acts used in Toba Dream movie. This research was conducted by using descriptive qualitative method. The data of the study were all utterances uttered by the main character in Toba Dream movie and collected by watching the movie. The result of the study showed that there were four types of indirect speech acts found in Toba Dream movie, they were: representative, directive, commisive, expressive containing indirect speech acts in Toba dream Movie. Representative $(25,71 \%)$ were realized by interrogative sentences and imperative sentences. Directive $(21,43 \%)$ were realized by declarative sentences and interrogative sentences. Commisive $(14,28 \%)$ were realized by declarative sentences. The main characters in Toba dream movie dominated the use of indirect speech act to express statement, command and warning. It showed that they could produce the language more politely and keep the hearer's face while getting instruction or information indirectly.
\end{abstract}

Keywords: indirect speech act, movie pragmatic, Toba Dream

\section{INTRODUCTION}

As a social being, human cannot live alone in this world. They need someone else in their life. Consequently, they should be able to communicate with the other to fullfil their nature as social being. Every day people have to communicate to each other in their life. When they communicate, they produce words that utter as form of language. In communicating with others, people use a language as a means of communication.

Language is one of the most fundamental aspects of human behavior and a defined instrument of expression and communication. There are many kinds of language that can be used to convey our intentions and thoughts. Yule (1996) says that language is a sound of symbols that convert some words in mind into a sentence of spoken words. Trudgill (2007) states that language is a society can be reflected through the language. There are three factors reflected in language. Those are physical environment, social environment, and social values. Physical environment is a circumstance or a place in which group of people live in a small town that have differences in speaking from one who live in a big town. Social environment can be reflected in a language especially in the field of vocabulary and pronunciation. Social values are a set of norms and tradition owned by a society. The norms and tradition can be reflected in a language because society's norms and tradition are different from other societies.

There are some fields of linguistics studies like phonology, morphology, syntax, semantic, and pragmatic that focus on certain field of study, like phonolgy focuses on study of sounds of a language, morphology is about a study of form of 
words, syntax is a study of word combinations into phrase and sentences, and semantic is a branch of linguistic that learns about literal meaning of word.

One of the important of linguistic fields is pragmatics. It has some definition from the experts. Pragmatics studies the use of language by humans as determined by the conditions of a society (Mey, 1993: 6). It means the language that people use depends on the social conditions where they live. That the pragmatic is the study of the speaker's meaning (Yule, 1996:3). It is more complicated than others because it has the contextual meaning between the speaker and the hearer. When the message from the speaker is not delivered to the hearer, the meaning from the speaker cannot be understood.

In pragmatics, there is a specific approach to understand the meaning of language. It is called speech acts which is action performed via utterances. Speech acts is one of pragmatic fields. It shows a human activity in a language and pragmatics studies the way people act through their speech. Speech act theory puts stress on the use of language. As language is the act of doing something, the study of speech act studies how someone expresses something like promising, thanking, requesting, apologizing. It means that when someone tells something, they also does something.

Speech act is everything which we do at the time of conversing or set of discussion verbal owning function (Austin, 1962: 94). Austin first introduced the idea of speech act, analyzing the relationships between utterances and performances. Speech acts usually appears in the first person, and use the simple present tense, indicative. Speech acts are not descriptive, instead they are pronounced to affect an actual situation, speech acts usually do not refer to the past events. Speech act is the action performed by language to modify the state of the object on which the action performed.

There are two general types of speech act: direct speech act and indirect speech act (Yule, 1996:54). Direct speech act, whenever there is direct relationship between structure and function (the structure and the function is congruent) or it means when we speak we do mean exactly the same as the literal meaning of what we say. Indirect speech act, whenever there is indirect relationship between structure and function. Indirect speech act are generally associated with the greater politeness in English than direct speech act.

The previous research about indirect speech act was conducted by Fatmalasari (2012) who analyzed of Indirect Speech Acts in "The Help" Film By Tate Tylor". She used Yule's theory to containing the utterances and Searle's theory to classifying. The result of her research showed there are utterances that contain indirect speech acts.it classified into requesting and questioning. Based on her result that can be concluded, indirect speech act are categorized into directive and commissive that types used by the characters in The Help film. The characters used directive and commisive indirect speech acts in requesting and questioning, offering and threatening.

Another research about indirect speech acts was conducted by Maghfira (2014). She observed the use of direct and indirect speech acts between higher and lower social class in Titanic movie. Based on Yule's theory, the result of the 
research showed higher and lower social classes use both direct and indirect speech act to communicate.

From the previous research above, the researcher choose movie as the data to prove that indirect speech act are used in society. The researcher used movie from Indonesia, "Toba Dream" movie. Toba Dream is one of the best movies in Indonesia. This movie awarded six nominations in Indonesian Film Festival (https://www.kompasiana.com/sutiono/564eclec759373e3068bbee3/toba-dreamsdrama-manusia-antar-budaya-dan-agama), beside the movie is interesting, it has utterances indicating indirect speech acts. Toba Dreams is an Indonesian movie adapted from a novel of the same title by T.B. Silalahi. The movie categorized as drama movie. The story of the movie is about a son that want proof to his father he can be success by the way that he choose.

Sergeant Tebe likes discipline his children, just like when he discipline his men on battlefield. Tebe ask his eldest son, Ronggur went to priest school. And Tebe ask sumurung follow the military academic school. While taruli, Tebe want her to go the best high school in Soposurung.

The characteristic of Tebe's children are very different. Ronggur is the most stubborn same as Tebe's and against any Tebe's proposals. Sumurung is more polite, even though he fights but in subtle way. For example when Sumurung states that he is not fit to enter the military academy and wants to enter priest school. While the youngest is very obedient, even though she actually rebelled behind her.

From characterization of the characters, the researcher assumption they use indirect speech act when they talk. For example, the researcher found the utterance in the movie:

S: Pak.

T: Kenapa? Hmm.

S: Saya tahu bapak ingin ada perwira di keluarga kita. Saya ingin

memenuhi permintaan bapak. Tapi saya sadar kemampuan saya... saya tidak sekuat yang bapak kira. Dan sebenarnya saya tak ingin masuk akademi militer

T:.. (Mendengar)

S: Namun, saya akan coba memenuhi permintaan bapak lainnya.

Meneruskan tradisi keluarga, jadi pendeta.

T: Sumurung.. kau boleh menetukan apa saja yang kau inginkan!

Based on the examples above, the utterance is classified as an indirect speech act as the command is realized by declarative sentence. The researcher interest to study indirect speech acts in Toba Dreams film by Benni Setiawan. The movie uses many indirect utterances so that the researcher wants to understand the story of the movie by analyzing the indirect utterances which are used by the characters.

\section{Pragmatics}

Pragmatic is the study of the relations of signs to interpreter (Levinson,1983:1). Meanwhile, Yule, (1996:3) states that there are four areas which pragmatic is concerned with:

a. Pragmatic is the study of speaker meaning.

b. Pragmatic is the study of contextual meaning. 
c. Pragmatic is the study of how to get more communicated than it is said.

d. Pragmatic is the study of the expression of relative distance.

Based on the definition mentioned earlier, pragmatics is a branch in linguistics which discusses the meanings of utterances and their functions, what is for and used for. In other words, pragmatic is a part in linguistics which focuses on utterances expressed by the speaker which is associated with its contexts.

\section{Speech Acts}

Levinson (1983:227) says that a speech act is a quite essentially pragmatics because it is created when the speaker makes an utterance to the heaer in context and must be interpreted as an aspect of social interaction. All of issues in the general theory of language usage, speech act theory has probably roused the widest interest.

Speech act means actions performed via utterances (Yule, 1996:48). Thus, people do things with words in much the same way as they perform physical actions. The action is performed by producing an utterance will consist of three related acts. They are locutionary act, illocutionary act, and perlocutionary act.

\section{Clasification of Speech Acts}

There are five basic kinds of speech act of utterance that one can perform in speaking which are promoted by Searle in Levinson (1983: 240), they are representatives, directives, commissives, expressive, and declarations.

Representatives are those kinds of speech act that the utterances commit the speaker to the truth of the expressed proposition (paradigm cases: asserting, concluding, etc.). Directives are those kinds of speech act that speakers use to get someone else to do something (paradigm cases: requesting, questioning, command, orders, suggesting, etc.). Commissives are those kinds of speech act that the utterances commit the speaker to some future course of action. (Paradigm cases: promising, threatening, offering, refusal pledges, etc.). Expressive are those kinds of speech act that the utterances express a psychological state (paradigm cases: thanking, apologizing, welcoming, and congratulating). Declarations are those kinds of speech act that the utterances effect immediate changes in the institutional state of affairs and which tend to rely on elaborate extra- linguistic institutions (paradigm cases: excommunicating, declaring war, christening, firing from employment).

\section{Sentence Structure and Sentence function}

According to Yule (1996: 54) there are three structural forms in English, namely declarative, interrogative, imperative. Declarative is a sentence in which the subject precedes the finite (Gerot and Wignel, 1994:38). Interogative is a sentence in which the finite precedes the subject (Gerot and Wignel, 1994:39) and Imperative is a sentence beginning with finite. According to Gerot and Wignel (1994:41), in imperatives the mood element may consist of subject precedes finite, subject only, finite only, or they may have no mood element. There will always be a predicator. 
The three general communications functions are statement, question, command or request. Statement is a sentence primarily used to convey information. The sentence function is statement. Question is sentence primarily used to elicit information and Command is a sentence primarily used to tell someone to do something.

\section{RESEARCH METHODOLOGY}

This study was conducted by using descriptive qualitative method. According to Bogdan and Biklen (1982) qualitative research is as direct source of the data and the researcher is the key instrument, qualitative means to find out how a theory works in different phenomena whose data collected are in the form of words rather than number. And qualitative research has the natural setting as the direct source. It means that qualitative research is study things in their natural settings, attempting to make sense or to interpret phenomena in terms of the meaning people bring to them. According to Borg and Gall (1989) descriptive research is unique in the number of variable employed. Like other research, descriptive research can include multiple variables for analysis, yet unlike other methods, it requires only one variable.

Related to this study, it described indirect speech acts in Toba Dream which were all conversation of the main characters from the movie were analyzed without any intervention to the data.

The data in this research were taken from a movie under the title of Toba Dream directed by Benny Setiawan. The film indicated utterances from the main characters which expressed indirect speech act. The movie was downloaded from the internet resources (http//:www.lk21.tv).

The technique of collecting data applied in this study was by using several steps, searching the movie, watching the movie, and writing the movie script.

\section{RESEARCH FINDINGS AND DISCUSSIONS}

There were 4 type of indirect speech acts found from 70 utterances, they are representative, directive, commisive, expressive containing indirect speech acts in Toba dream Movie. Representative used the main character as statement are dominating act which is identified as indirect speech act $(25,71 \%)$ utterances. They were represented in 9 interrogative sentences and 9 imperative sentences. The second was directive used the main character as command acts $(21,43 \%)$ utterances which were realized by 12 declarative sentences and 3 interrogative sentences. The third was commisive used the main character as warning act $(14,28 \%)$ utterances which were realized by declarative sentences.

2. The main characters in Toba dream movie dominantly used indirect speech act to express statement, command and warning. It showed that they produced the language more politely and they can kept the hearer's face getting instruction or information indirectly. 


\section{DISCUSSION}

Maghfira (2014) in her research about The Use Of Direct and Indirect Speech Acts Between Higher And Lower Social Class in Titanic Movie. She concluded in her research that Based on George ${ }^{\text {es }}$ Yule theory, speech acts can be divided into two ways of speaking, direct and indirect speech acts. From the analysis in Titanic movie, there were assertives, directives, commisives, expressives, and declarations speech acts exist. According to the analysis both of direct and indirect speech acts used to communicate.

Meanwhile in this study, the researcher found types of indirect speech act used in Toba Dream movie. there were representative, directive, commisive and expressive. The used declaration by the main characters didn't find in Toba Dream movie.

On the other hand this research was supported by Fatmalasari research (2012) who analyzed indirect speech act in The Help film by Tate Taylor. It concluded that the types of indirect speech acts used by the character in The Help film were directive and commisive. The characters used directive and commisive indirect speech acts in requesting, questioning, threatening, and offering.

In Toba Dream movie, the main characters used types of indirect speech act like representative, directive, commisive expressive to showed statement, command, warning, Question, Request, Refuse, Apologize, Threat, Promise and Thank.

\section{CONCLUSIONS AND SUGGESTIONS}

\section{Conclusions}

There were 4 types of indirect speech act used in Toba Dream movie, such representative, directive, commisive and expressive. Representative speech acts used by the main characters as statement were dominating act. Directive speech acts were used by the main character as command and commisive speech act were used by main character as warning

The main characters in Toba dream movie dominantly used indirect speech act to express statement, which were realized into interrogative sentences and imperative sentences, while commands were realized into declarative sentences and interrogative sentences, then warning realized by declarative sentences. It showed that they produced the language more politely and they could keep the hearer's face while getting instruction or information indirectly.

\section{Suggestions}

1. For the other researchers and the references in guiding to collect further information of indirect speech act which conducted in different ethnic movie to enrich the knowledge of the researcher and the reader in the field of culture.

2. This study can be as reference to the study of pragmatics terms especially indirect speech acts in the movie.It can be helpful for to readers to understand Toba Dream. It also gives more information for the learners who are interested in improving the findings of study. 


\section{REFERENCES}

Amanda, V. and Marlina, L. 2018. Directive Speech Acts Used In Frozen Movie Transcript. E-Journal of English Language and Literature Volume 7 No 1. 218-226.

Austin, J.L. 1962. How To Do Things With Words. London: The Clarendon. Press

Bodgan and Biklen. 1982. Qualitative Research For Education. Toroto: Alyn and Bacon.

Borg,WR and Gall, M.G. 1989. Educational Research: An Introduction [5 ${ }^{\text {th }}$ Edition]. Newyork: Longman.

Fatmalasari, I. 2012. Pragmatics Analysis Of Indirect Speech Acts in “The Help” Film Tate Taylor. Semarang. Dian Nuswantoro University.

Gazdar, G. 1979a. Pragmatics: Implicature, Presupposition and Logical Form. New York: Academic Press

Gerot, L. and Wignel, P. 1994. Making Sense of Functional Grammar. Gred Stabler: Antipodean Educational Enterprises (AEE).

Grundy, P. 1995. Doing Pragmatics. New York: Edward Arnold

Hufford, James, R. and Brendan Heasley. 1983. Semantic. Acourse book: Cambridge University Press.

Leech,Geoffrey. 1983. Principles of Pragmatics. London: Longman.

Levinson, S.C. 1983. Pragmatics. Cambridge: Cambridge University Press

Maghfira, Isna, K. 2014. The Use Of Direct and Indirect Speech Acts Between Higher And Lower Social Class in Titanic Movie.

Mayoni, Kadek, I. 2014. Direct And Literal Dimensions Of Speech Acts In The Movie Of "Paranorman".

Mey, Jacob L. 1993. Pragmatics: An Introduction. Oxford and Cambridge: Blackwell

Muhartoyo. and Kristiani, K. 2013. Directive Speech Act In The Movie "Sleeping Beauty". Journal Of Humaniora Vol.4 No.2 Oktober 2013: 949-966. Retrieved June $2^{\text {nd }} 2018$

Parker, F., 1986. Linguistics for Non-linguists, Department of English Louisiana. State University, London.

Searle, J.R. 1969. Speech Acts. London: Cambridge University Press.

Searle, J.R., Kiefer, F \& Bierwisch, M. (eds.). 1980. Speech Act Theory and Pragmatic. Synthese Language Library, vol. 10. Dordrecht: Reidel

Stewart, Thomas W. and Nathan Vaillette. 2001.Language Files: Materials for an Introduction to Language \& Linguistics. Columbus: The Ohio State University Press.

Trudgill, P. 2000. Sociolinguistics: Fourth Edition. London: Penguin Books

Van Dijk, Teun A. 1977. Text and Context : Exploration in the Semantics and Pragmatics Of Discourse. London : Longman.

Yule, G.1996. Pragmatics. London: Oxford University Press.

https://simple.wikipedia.org/wiki/Movie. Retrieved on $12^{\text {th }}$ Desember 2018. At 3.42 PM

https://www.kompasiana.com/sutiono/564eclec759373e3068bbee3/toba-dreamss-drama-manusiaantar-budaya-dan-agama. Retrieved on 11th Desember 2018. At 8.08 AM. 